\title{
Pemanfaatan Teknologi Machine Learning Untuk Klasifikasi Wilayah Risiko Kekeringan di Daerah Istimewa Yogyakarta Menggunakan Citra Landsat 8 Operational Land Imager (OLI)
}

\author{
Fajar Ayuningtyas ${ }^{1}$, Sri Yulianto Joko Prasetyo ${ }^{2}$ \\ ${ }^{1}$ Fakultas Teknologi Informasi, Universitas Kristen Satya Wacana, Salatiga, email : \\ 672016296@student.uksw.edu \\ Jln. Dr. O. Notohamidjojo, Kel. Blotongan, Kec. Sidorejo, Kota Salatiga, 50715, Jawa Tengah, \\ Indonesia, email: fti@uksw.edu \\ ${ }^{2}$ Fakultas Teknologi Informasi, Universitas Kristen Satya Wacana, Salatiga, email : \\ sri.yulianto@uksw.edu \\ Jln. Dr. O. Notohamidjojo, Kel. Blotongan, Kec. Sidorejo, Kota Salatiga, 50715, Jawa Tengah, \\ Indonesia, email: $\underline{\text { tti@uksw.edu }}$
}

\section{ARTICLE INFO}

Article history:

Received 06 April 2020

Received in revised form 07 April 2020

Accepted 09 April 2020

Available online 30 July 2020

\begin{abstract}
Drought is a natural disaster that occurs slowly and lasts a long time. Bantul and Gunung Kidul Regencies, Special Region of Yogyakarta are also areas affected by high drought risk. This happened because the area was the result of the construction of a cement factory and limestone mining along the Sewu Mountains. Prediction and classification of areas affected by drought can be done more accurately over large areas by extracting vegetation indices through remote sensing imagery. This research was conducted to provide information about the potential risk of drought in the region using Landsat 8 OLI spectral vegetation index data. Prediction or classification of drought potential using Artificial Neural Network (ANN). Vegetation index used in this study is NDVI, TCI, VCI, and VHI. Correlation results between vegetation indices showed the highest correlation occurred between the vegetation index TCI and VHI with the potential for a medium drought of 0.501 and the potential for a high drought of 0.684 . Also obtained are the results of the classification of 9 villages that fall into the category of high drought potential (High Risk). Accuracy results and Kappa values indicate that Random Forest is the best method used with a breakdown of values of $99.91 \%$ and $99.81 \%$, respectively. Spatial prediction results are performed using Inverse Distance Weighted (IDW) on vegetation index and prediction. Testing of spatial relationships between villages that have the potential for drought is done using Moran's I. analysis.
\end{abstract}

Keywords: Drought, ANN, Vegetation Index, Remote sensing, IDW, Moran's I. 


\section{Pendahuluan}

Indonesia merupakan negara dengan bentuk topografi yang beragam dan sangat kompleks serta memiliki wilayah perairan yang sangat luas. Hal tersebut menjadikan Indonesia memiliki variabilitas iklim yang sangat tinggi. Keadaan iklim yang tinggi menyebabkan adanya kejadian yang disebut ekstrim basah dan ekstrim kering. Salah satu contoh bencana esktrim kering yaitu kemarau berkepanjangan yang berdampak besar dalam kehidupan manusia. Dengan kondisi negara memiliki variabilitas iklim sangat tinggi menjadikan Indonesia sebagai negara rawan bencana [1][2].

Maplecroft (2010) melakukan penilaian tentang risiko bencana dan menempatkan Indonesia sebagai negara yang berisiko ekstrim terkena bencana peringkat 2 setelah Bangladesh. Hasil penilaian tersebut tidak dapat dipungkiri mengingat kondisi geografi dan geologi Indonesia yang terletak pada pertemuan tiga lempeng Indoaustralia, Pasifik dan Eurasia serta berada pada lintasan "Ring of Fire" [1][2][3]. Indonesia juga terdapat jajaran Pegunungan Sewu yang terbentang sepanjang pantai selatan Kabupaten Gunung Kidul, Kabupaten Wonogiri, hingga Kabupaten Tulungagung di Pulau Jawa [2]. Deretan pegunungan jenis karst tersebut pada beberapa wilayah sudah mulai merusak ekosistem seperti sumber air sejak pabrik semen dan penambangan kapur didirikan, sehingga wilayah tersebut rentan terkena bencana kekeringan.

Kekeringan merupakan suatu bencana alam yang terjadi secara perlahan dan dapat berlangsung lama hingga musim penghujan tiba. Terjadinya bencana kekeringan memberikan dampak yang meluas dalam berbagai bidang (ekonomi, sosial, kesehatan, pendidikan, dll) [4]. Risiko dari bencana kekeringan dalam kehidupan manusia ialah kekurangan air, kerusakan sumber daya ekologi, berkurangnya sumber daya pertanian serta dapat menyebabkan kelaparan bahkan korban jiwa. Datangnya bencana kekeringan tidak dapat dipastikan secara tepat, namun secara umum fenomena kekeringan sering terjadi dikarenakan siklus kejadian El Nino [5][6][7].

Berdasarkan latar belakang di atas, maka dilakukan penelitian untuk melakukan klasifikasi atau prediksi wilayah risiko menggunakan citra satelit dengan Machine Learning Autocorrelation dan metode Artificial Neural Network. Wilayah yang menjadi studi kasus penelitian ini yaitu daerah sekitar Pegunungan Sewu yang sebagian besar wilayahnya terdiri dari pegunungan karst pada kabupaten Bantul dan Gunung Kidul provinsi Daerah Istimewa Yogyakarta [2]. Selain pertimbangan lokasi yang berpotensi terkena kekeringan namun juga melihat dari hasil kaji dalam Indeks Risiko Bencana Indonesia 2013 berdasarkan pada Standarized Precipitation Index (SPI) menunjukkan bahwa kabupaten Bantul dan Gunung Kidul termasuk dalam kota/kabupaten dengan risiko kekeringan kelas risiko tinggi [1][2]. Analisis wilayah kekeringan menggunakan indeks vegetasi NDVI, VCI, TCI dan VHI. Peneltian ini berbasis citra landsat-8 OLI dimana hasil yang didapatkan dapat dijadikan sebagai informasi untuk mengetahui klasifikasi wilayah risiko kekeringan sehingga memberikan kemudahan dalam menentukan tindakan yang tepat dalam menghadapi bencana kekeringan.

\section{Metode Penelitian}

Studi kasus sebagai sampel penelitian yaitu 177 desa di Kabupaten Bantul dan Gunung Kidul, Provinsi Daerah Istimewa Yogyakarta, Indonesia. Data yang digunakan untuk penelitian ini adalah data penginderaan jauh diperoleh dari United States Geological Survey (USGS) https://earthexplorer.usgs.gov/ berupa data bulanan citra satelit Landsat 8 OLI (Operational Land Imager) tahun 2018 - 2019 dengan path/row 120/65. 


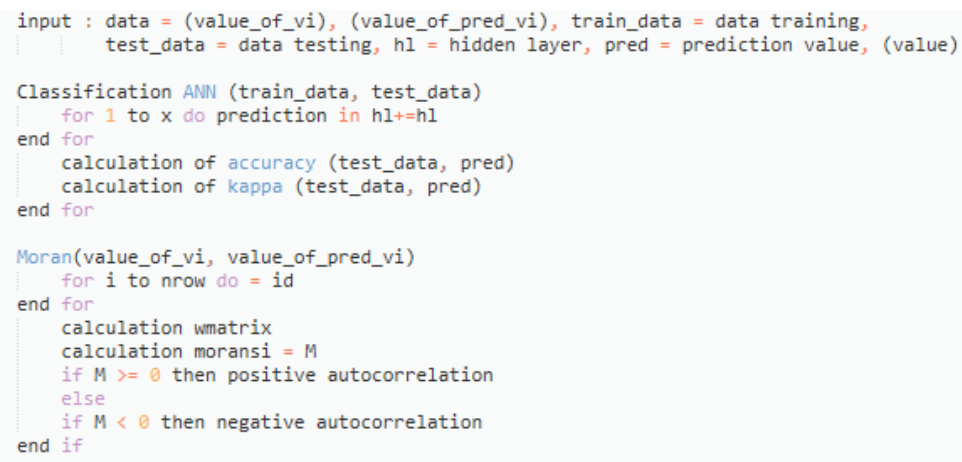

Gambar 1. Pseudocode dari proses klasifikasi dan prediksi data

Gambar diatas menunjukkan struktur atau prses klasifikasi dan prediksi data menggunakan pseudocode untuk memahami alur logika penelitian. Metode penelitian menunjukkan proses penelitian seperti pada Gambar 2 dengan rincian 4 (empat) inti proses penelitian diantaranya:

1. Pemrosesan Data, data yang dipergunakan merupakan citra Landsat 8 OLI, didalamnya terdapat 11 band yang memiliki nama dan panjang gelombang berbeda. Tiap band memiliki panjang gelombang antara 0.43 - 12.51. Untuk mendapatkan hasil indeks vegetasi berupa angka diperlukan proses kombinasi band dengan melakukan perhitungan sesuai rumus NDVI, VCI, TCI, dan VHI. Perhitungan dilakukan menggunakan software Qgis 2.8.1, hasil yang didapatkan berupa angka yang nantinya dapat dikelompokkan berdasarkan indeks secara manual sesuai dengan kelas indeks. Data indeks vegetasi VCI dan VHI tahun 2019 memberikan nilai kosong sehingga dilakukan Interpolasi Linier. Pada tahapan ini pula dilakukan pengujian tingkat korelasi tiap indeks untuk mengetahui hubungan antar indeks yang digunakan.

2. Pengujian Data dan Klasifikasi, data yang telah diklasifikasi secara manual berdasarkan kategori tiap indeks vegetasi dibagi menjadi 2 kelas tingkat kekeringan, yaitu kekeringan potensi sedang (Middle Risk) dan kekeringan potensi tinggi (High Risk). Data yang berisi indeks vegetasi tiap desa diklasifikasikan menggunakan metode ANN dengan pembagian training data sebanyak $75 \%$ dan testing data untuk pembelajaran sebanyak $25 \%$ dari keseluruhan data.

3. Uji Performa Metode, untuk melakukan pengujian kinerja metode yang digunakan maka perlu melakukan analisis data menggunakan metode lain. Metode lain yang digunakan adalah SVM , Random Forest dan $k$-Nearest Neighbour. Klasifikasi dan prediksi menggunakan indeks vegetasi dilakukan menggunakan bahsa pemrograman $\mathrm{R}$ dan dikelmpokkan menjadi dua kelas yaitu wilayah berpotensi kekeringan sedang dan tinggi.

4. Distribusi spasial hasil klasifikasi ANN menggunakan IDW dan memvisualisasikan hasilnya menjadi peta sebaran wilayah risiko kekeringan. Dan juga dilakukan perhitungan Moran's I untuk mengetahui hubungan spasial antar wilayah untuk menentukan pola distribusi wilayah yang mengalami kekeringan. 


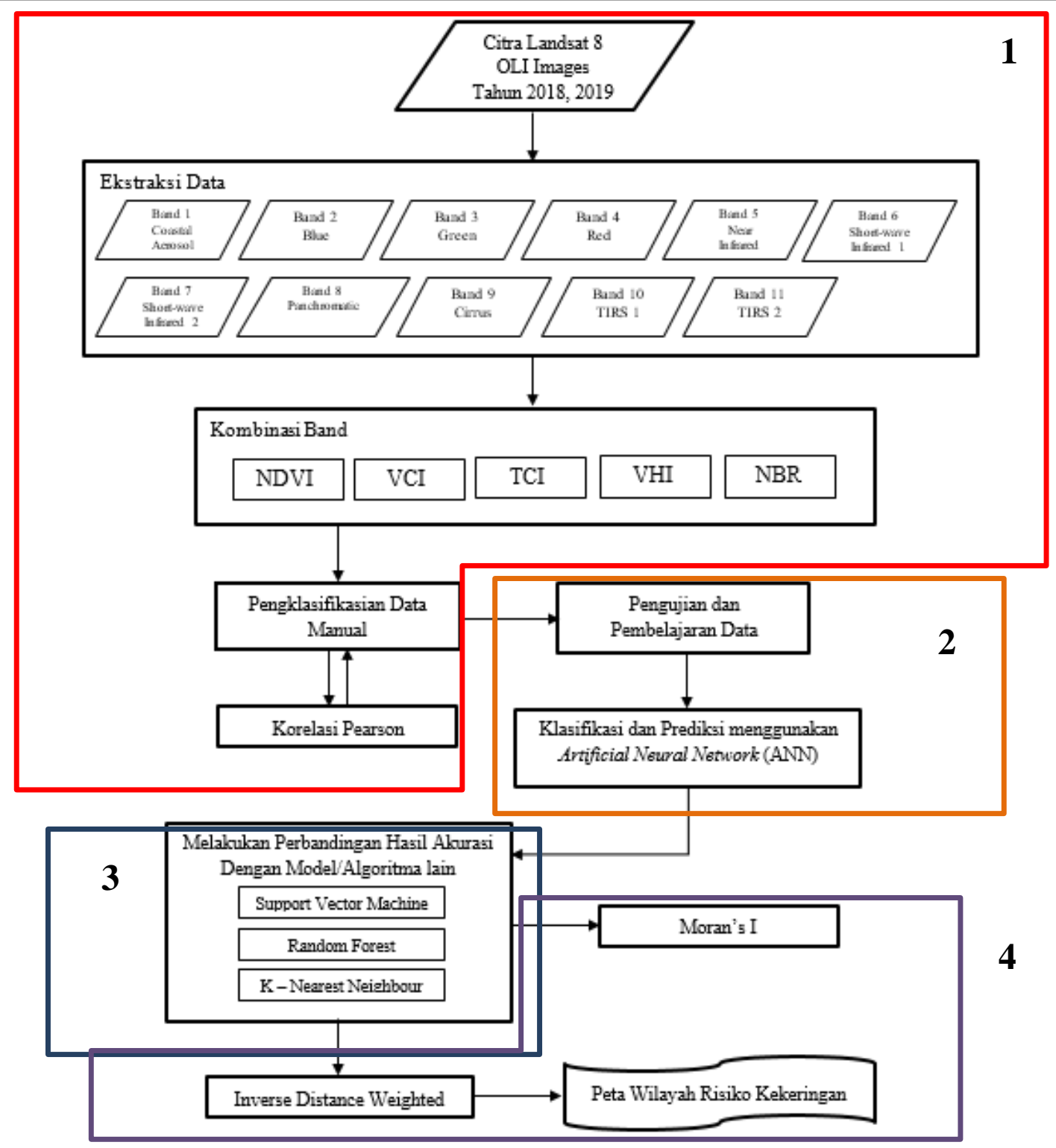

Gambar 2. Metode Penelitian

Indeks vegetasi merupakan hasil yang didapatkan menggunakan data citra satelit dan diolah menggunakan persamaan tertentu dan didasarkan pada perbedaan penyerapan maksimum radiasi di kanal merah sebagai hasil pigmen klorofil dan reflektansi maksimum di kanal spektral infra merah dekat Near Infra Red (NIR) sebagai akibat dari struktur selular daun [8][9]. Beberapa penelitian membutikan bahwa indeks vegetasi spektral yang dihasilkan dari kalkulasi data reflektansi visible dan NIR berhubungan secara linier dengan jumlah radiasi aktif yang diserap oleh kanopi tumbuhan selama proses fotosintesis [10]. Indeks vegetasi yang digunakan sebagai indikator potensi kekeringan diantaranya: NDVI, TCI, VCI dan VHI. Beberapa indeks yang digunakan dibuat menggunakan beberapa rumus:

a. NDVI

Normalized Difference Vegetation Index (NDVI) merupakan indeks vegetasi yang sering digunakan untuk membandingkan tingkat kehijauan vegetasi (tingkal klorofil) pada tumbuhan. Pengelompokkan nilai tiap kelas berdasarkan indeks vegetasi NDVI ditunjukkan pada Tabel1 [11][12].

TRANSFORMATIKA Vol. 18, No. 1, July 2020: 13-24 


$$
N D V I=\frac{N I R-R}{N I R+R}=\frac{\text { Band } 5-\text { Band } 4}{\text { Band } 5+B \text { and } 4}
$$

Tabel 1. Klasifikasi Nilai NDVI

\begin{tabular}{ccc}
\hline Kelas & Nilai NDVI & Klasifikasi \\
\hline 1 & $-1 \mathrm{~s} / \mathrm{d}-0.03$ & $\begin{array}{c}\text { Tidak } \\
\text { bervegetasi }\end{array}$ \\
\hline 2 & $-0.03 \mathrm{~s} / \mathrm{d} 0.15$ & $\begin{array}{c}\text { Kehijauan } \\
\text { sangat } \\
\text { rendah }\end{array}$ \\
\hline 3 & $0.15 \mathrm{~s} / \mathrm{d} 0.25$ & $\begin{array}{c}\text { Kehijauan } \\
\text { rendah }\end{array}$ \\
\hline 4 & $0.26 \mathrm{~s} / \mathrm{d} 0.35$ & $\begin{array}{c}\text { Kehijauan } \\
\text { sedang }\end{array}$ \\
\hline 5 & $0.36 \mathrm{~s} / \mathrm{d} 1.00$ & $\begin{array}{c}\text { Kehijauan } \\
\text { tinggi }\end{array}$ \\
\hline
\end{tabular}

b. TCI

Temperature Condition Index (TCI) digunakan untuk menentukan tekanan pada vegetasi yang disebabkan oleh suhu dan kelembaban yang berlebihan. Keadaan diperkirakan relatif terhadap suhu minimum dan suhu maksimum serta dimodifikasikan untuk mencerminkan respon vegetasi yang berbeda terhadap suhu. Pengelompokkan nilai indeks vegetasi TCI ditunjukkan pada Tabel 2 [13][14].

$$
T C I=100 \times \frac{L S T_{\max }-L S T}{L S T_{\max }-L S T_{\min }}
$$

c. VCI

Vegetation Condition Index (VCI) memisahkan naik turunnya EVI terkait cuaca jangka pendek dari sebuah penelitian jangka pendek dari sebuah perubahan eksosistem jangka panjang. Oleh karena itu VCI dapat digunakan sebagai salah satu indeks untuk mengidentifikasi tekanan vegetatif karena kondisi kelembaban. Nilai indeks vegetasi VCI dikelompokkan menjadi beberapa kelas seperti pada Tabel 2 [14][15].

$$
V C I=100 \times \frac{E V I-E V I_{\min }}{E V I_{\max }-E V I_{\min }}
$$

Tabel 2. Klasifikasi Nilai TCI dan VCI

\begin{tabular}{cc}
\hline Nilai TCI dan VCI & Klasifikasi \\
\hline 0 s/d 10 & $\begin{array}{c}\text { Kekeringan } \\
\text { sangat ekstrim }\end{array}$ \\
\hline 10 s/d 20 & $\begin{array}{c}\text { Kekeringan } \\
\text { berat }\end{array}$ \\
\hline 20 s/d 30 & $\begin{array}{c}\text { Kekeringan } \\
\text { sedang }\end{array}$ \\
\hline 30 s/d 40 & $\begin{array}{c}\text { Kekeringan } \\
\text { rendah }\end{array}$ \\
\hline$>40$ & $\begin{array}{c}\text { Tidak } \\
\text { kekeringan }\end{array}$ \\
\hline
\end{tabular}


d. VHI

Vegetation Health Index (VHI) adalah salah satu indeks kekeringan pertanian yang mengacu pada kondisi vegetasi. Pengelompokkan kelas kekeringan untuk nilai indeks vegetasi VHI ditunjukkan pada Tabel 3 [14].

$$
V H I=\alpha V C I+(1-\alpha)=0.5(V C I+T C I)
$$

Tabel 3. Klasifikasi Nilai VHI

\begin{tabular}{cc}
\hline Nilai VHI & Klasifikasi \\
\hline $1 \mathrm{~s} / \mathrm{d} 23$ & $\begin{array}{c}\text { Kekeringan } \\
\text { sangat ekstrim }\end{array}$ \\
\hline $24 \mathrm{~s} / \mathrm{d} 41$ & $\begin{array}{c}\text { Kekeringan } \\
\text { berat }\end{array}$ \\
\hline $42 \mathrm{~s} / \mathrm{d} 63$ & $\begin{array}{c}\text { Kekeringan } \\
\text { sedang }\end{array}$ \\
\hline $64 \mathrm{~s} / \mathrm{d} 85$ & $\begin{array}{c}\text { Kekeringan } \\
\text { rendah }\end{array}$ \\
\hline $86 \mathrm{~s} / \mathrm{d} 125$ & $\begin{array}{c}\text { Tidak } \\
\text { kekeringan }\end{array}$ \\
\hline
\end{tabular}

Pada saat melakukan kombinasi band keseluruhan data apabila mendapatkan nilai kosong pada indeks vegetasi maka dilakukan Interpolasi Linier agar data yang diolah tetap lengkap [16]. Persamaan untuk mendapatlan nilai suatu titik menggunakan Interpolasi Linier sebagai berikut:

$$
\frac{y-y_{0}}{x-x_{0}}=\frac{y_{1}-y_{0}}{x_{1}-x_{0}}
$$

Tahapan klasifikasi dan prediksi yang dilakukan pertama kali adalah menghitung indeks vegetasi yang nantinya dikelompokkan berdasarkan klasifikasinya dan diolah menggunakan metode: (1) ANN, (2) Random Forest, (3) Support Vector Machine (SVM). ANN merupakan pola klasifikasi klasik yang dapat digunakan secara luas untuk mengatasi permaslahan yang relatif mudah digunakan [17]. Metode ini digunakan untuk klasifkasi dan prediksi dengan cara kerja meniru perilaku biologis syaraf. Didalamnya terdapat pengaturan untuk pemberian input layer, hidden layer dan output layer [18].

Setelah mendapatkan hasil prediksi atau klasifikasi menggunakan ketiga algortima maka dilakukan pengujian performa klasifikasi dengan mencari akurasi menggunakan Cohen's Kappa [19].

$$
Z_{j}=\frac{\sum_{i=1}^{n} \frac{Z_{i}}{\left(h_{i j}+8\right)^{\beta}}}{\sum_{i=1}^{n} \frac{1}{\left(h_{i j}+8\right)^{\beta}}} .
$$

Penentuan risiko wilayah yang berpotensi kekeringan dengan melakukan ditribusi indeks kekeringan disemua wilayah menggunakan interpolasi Inverse Distance Weighted (IDW). IDW merupakan metode deterministik sederhana dengan mempertimbangkan wilayah disekitarnya dan memerlukan parameter dan operator yang sedikit. Dimana $Z_{j}$ adalah nilai lokasi yang yang belum teruji, $Z_{i}$ adalah nilai yang sudah diketahui, $\beta$ merupakan nilai weight dan $\delta$ adalah parameter smoothing. Jarak pemisah antara titik yang diketahui dan titik yang belum diketahui diukur dengan jarak euclidean [19][20]:

TRANSFORMATIKA Vol. 18, No. 1, July 2020: $13-24$ 


$$
h_{\mathrm{ij}}=\sqrt{(\Delta x)^{2}-(\Delta y)^{2}}
$$

Dimana $\Delta x$ dan $\Delta x$ merupakan jarak antara titik yang tidak diketahui $j$ dan titik yang diketahui $i$ sesuai dengan sumbu referensi. Kemudian untuk perhitungan Moran's I dilakukan untuk mengetahui hubungan spasial karakteristik vegetasi antara titik pengambilan sample. Rumus persamaan Moran's I sebagai berikut [19]:

$$
l=\frac{N \sum_{i=1}^{n} \sum_{j=1}^{n} w_{i j}\left(x_{i}-\bar{x}\right)\left(x_{j}-\bar{x}\right)}{\left(\sum_{i=1}^{n} \sum_{j=1}^{n} w_{i j}\right) \sum_{i=1}^{n}\left(x_{i}-\bar{x}\right)^{2}}
$$

Dimana $\mathrm{N}$ merupakan jumlah pengujian yang dilakukan, $x$ adalah indeks vegetasi yang digunakan sebagai indikator pengujian dan variabel $w_{i j}$ merupakan weight antara wilayah yang diuji $i$ dan $j$.

\section{Hasil dan Pembahasan}

Data yang digunakan merupakan keseluruhan data hasil kombinasi band indeks vegetasi selama dua tahun yaitu tahun 2018 dan tahun 2019. Data terdiri dari 177 desa dari 2 kabupaten yaitu Kabupaten Bantul dan Gunung Kidul, provinsi Daerah Istimewa Yogyakarta. Dalam pemrosesan data dilakukan analisis korelasi untuk mengetahui hubungan antar indeks berdasarkan dua kelas wilayah potensi kekeringan sedang (Middle Risk) dan kekeringan tinggi (High Risk).

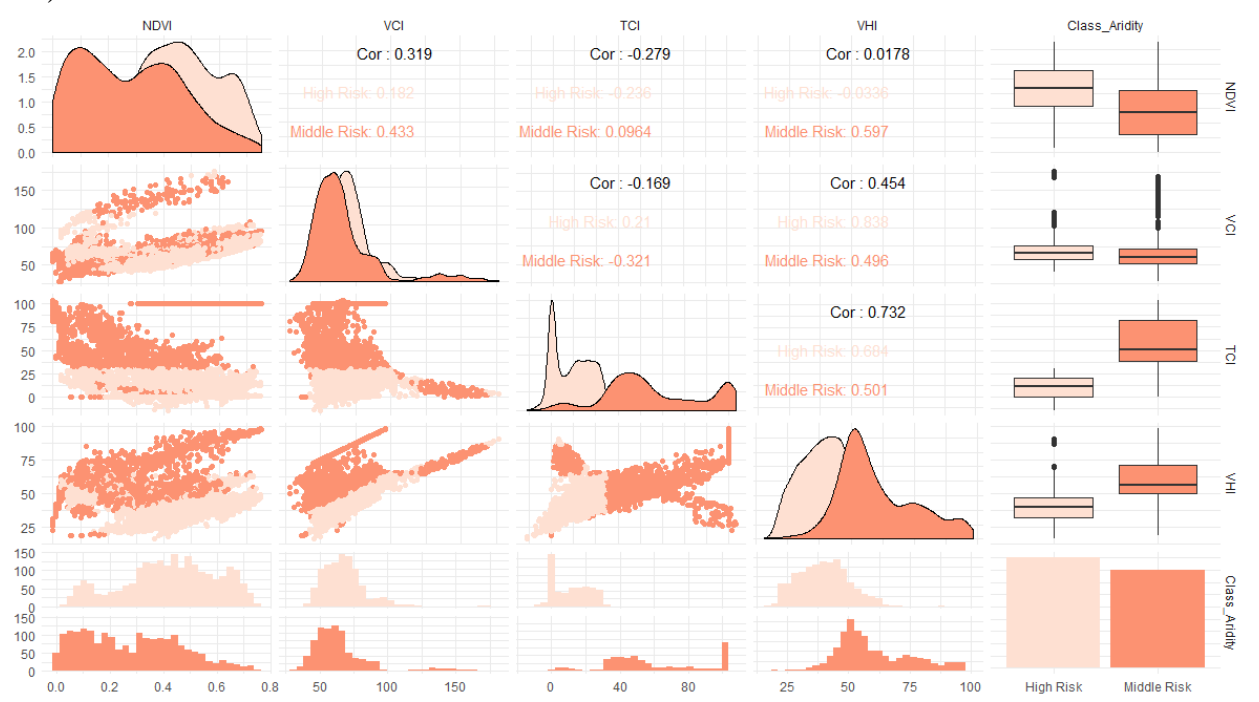

Gambar 3. Korelasi Pearson menggunakan analisis scatterplot

Berdasarkan hasil analisis pada Gambar 3 ditunjukkan bahwa hubungan antar indeks vegetasi terdapat hubungan yang memiliki korelasi positif namun juga terdapat hubungan yang memiliki korelasi negatif. Hubungan antara indeks vegetasi TCI dan VHI memiliki koefisien korelasi positif dan bernilai paling tinggi dimana potensi kekeringan sedang (Middle) sebesar 0.501 dan potensi kekeringan tinggi sebesar 0.684. VCI merupakan naik turunnya Enchanced Vegetation Index (EVI) terkait cuaca jangka pendek yang terjadi dari sebuah perubahan eksositem jangka panjang yang dapat digunakan sebagai salah satu indeks untuk mengidentifikasi tekanan negatif karena kondisi kelembaban. Sedangkan VHI merupakan indeks kekeringan pertanian yang mengacu pada kondisi vegetasi. Dan koefisien korelasi paling rendah antara TCI dengan NDVI dengan potensi kekeringan sedang sebesar 0.0964 dan potensi kekeringan tinggi sebesar -0.236. TCI digunakan untuk menentukan tekanan pada vegetasi yang disebabkan oleh kelembaban dan suhu yang berlebihan.

Pemanfaatan Teknologi Machine Learning Untuk Klasifikasi Wilayah Risiko Kekeringan di Daerah Istimewa Yogyakarta Menggunakan Citra Landsat 8 Operational Land Imager (OLI) 
Sedangkan NDVI merupakan indeks vegetasi yang sering digunakan untuk membandingkan tingkat kehijauan vegetasi (tingkat klorofil) pada tumbuhan. Selain nilai korelasi pada setiap indeks vegetasi, dengan grafik diatas dapat dilihat analisis data berupa densit, trend, histogram, boxplot dan barplot yang menunjukkan distribusi nilai antara kelas potensi kekeringan sedang (Middle Risk) dan potensi kekeringan tinggi (High Risk).

Selanjutnya adalah melakukan prediksi atau klasifikasi menggunakan ANN dengan jumlah hidden layer yang berbeda. Hal tersebut dilakukan untuk mendapatkan akurasi penggunaan metode ANN yang terbaik sehingga dapat digunakan untuk melakukan klasifikasi atau prediksi data. Setelah melakukan beberapa percobaan dengan nilai hidden layer yang bervariatif maka didapatkan nilai akurasi yang paing tinggi yaitu dengan penggunaan hidden layer sebanyak 1.

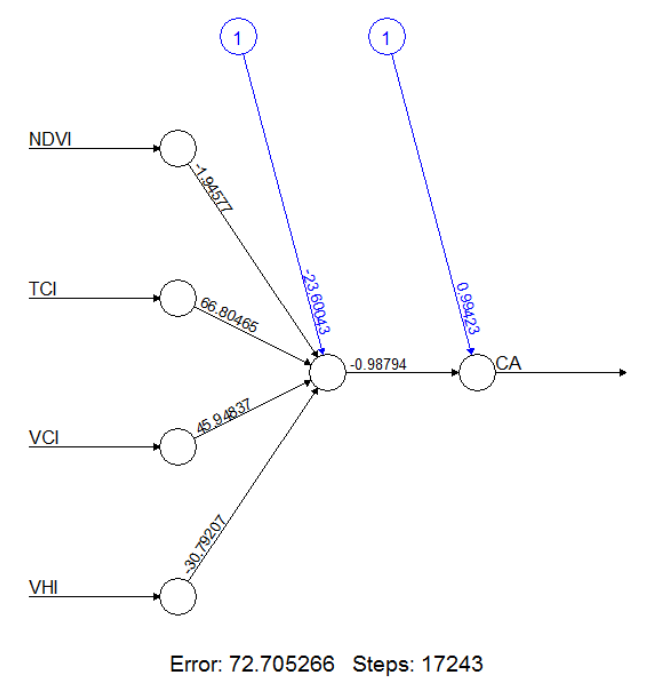

Gambar 4. Jaringan Hasil Prediksi ANN

Hasil prediksi dengan akurasi terbaik menunjukkan terdapat error sebanyak 72.705 dan memiliki 17243 langkah. Gambaran penggunaan metode ANN untuk prediksi data dapat dilihat pada Gambar 4. Prediksi seluruh data selama 2 (dua) tahun dilakukan menggunakan metode ANN dengan hidden layer sebanyak 1 dan dilakukan dengan bahasa pemrograman R. Hasil rata-rata tiap indeks selama dua tahun dilakukan prediksi sehingga mendapatkan beberapa desa yang masuk ke dalam kelas potensi kekeringan tinggi (High Risk) seperti pada Tabel 4.

Tabel 4. Hasil Prediksi Wilayah Potensi Kekeringan Tinggi

\begin{tabular}{ccc}
\hline Desa & Kecamatan & $\begin{array}{c}\text { Nilai Tingkat } \\
\text { Kekeringan }\end{array}$ \\
\hline Baleharjo & Wonosari & 0.670 \\
\hline Banguntapan & Banguntapan & 0.992 \\
\hline Jagalan & Banguntapan & 0.855 \\
\hline Logandeng & Playen & 0.795 \\
\hline Ngeposari & Semanu & 0.745 \\
\hline Ngestiharjo & Kasihan & 0.747 \\
\hline Sambirejo & Ngawen & 0.994 \\
\hline Tirtonirmolo & Kasihan & 0.615 \\
\hline
\end{tabular}

Langkah selanjutnya yaitu membandingkan dengan melakukan klasifikasi dengan metode yang berbeda untuk mendapatkan tingkat akurasi tiap metode. Nilai akurasi dan nilai Kappa

TRANSFORMATIKA Vol. 18, No. 1, July 2020: 13-24 
didapatkan untuk melihat perbandingan antara metode ANN, SVM, Random Forest dan kNN. Hasil pada Tabel 5 didapatkan menggunakan confusion matrix menunjukkan bahwa metode Random Forest dengan tingkat akurasi sebesar $99.91 \%$ lebih tepat digunakan dibandingkan dengan metode ANN, SVM dan k-NN, begitupula dengan nilai Kappa menunjukkan bahwa Random Forest memiliki nilai paling tinggi diantara metode yang lainnya yaitu sebesar $99.81 \%$.

Tabel 5. Perbandingan Akurasi dan Nilai Kappa

\begin{tabular}{ccc}
\hline $\begin{array}{c}\text { Metode } \\
\text { Klasifikasi }\end{array}$ & Akurasi & Kappa \\
\hline $\begin{array}{c}\text { Artificial Neural } \\
\text { Network }\end{array}$ & $93.88 \%$ & $87.68 \%$ \\
\hline $\begin{array}{c}\text { Support Vector } \\
\text { Machine }\end{array}$ & $98.4 \%$ & $96.77 \%$ \\
\hline Random Forest & $99.91 \%$ & $99.81 \%$ \\
\hline $\begin{array}{c}\text { k-nearest } \\
\text { neighbour }\end{array}$ & $99.34 \%$ & $98.67 \%$ \\
\hline
\end{tabular}

Klasifikasi data yang telah didapatkan kemudian divisualisasikan menggunakan boxplot di R dengan penjelasan bagian yaitu:

1. Pencilan atau outlier yang biasanya terdapat dibagian atas atau bawah boxplot

2. Nilai maksimum setelah pencilan dikeluarkan

3. Quartil tertinggi (Q3) merupakan angka terbesar 75 apabila diurutkan dengan quartil yang lain

4. Median (Q2) atau nilai tengah

5. Quartil terendah (Q1) merupakan angka terkecil apabila diurutkan dengan quartil yang lain

6. Nilai minimum setelah mencilan dikeluarkan
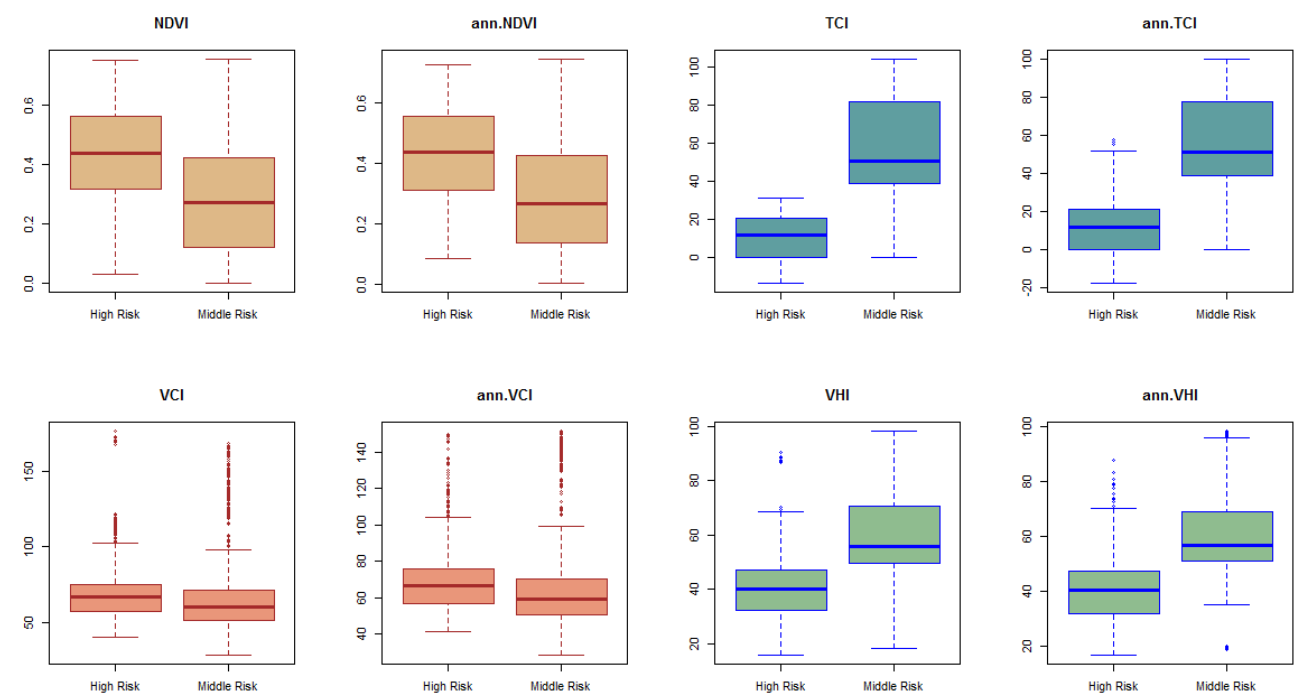

Gambar 5. Analisis boxplot antara potensi kekeringan sedang (Middle Risk) dan potensi kekeringan tinggi (High Risk)

Berdasarkan analisis boxplot pada Gambar 5 menunjukkan bahwa panjang box yang ditentukan IQR (Inter Quartile Range) pada tiap kelas kekeringan yaitu potensi kekeringan sedang dan potensi kekeringan tinggi memeiliki sedikit perbedaan antara indeks vegetasi hasil perhitungan yang sebenarnya dengan hasil prediksi menggunakan ANN. Semakin tinggi box 
menunjukkan bahwa data semakin menyebar. Sebagai contoh berdasarkan analisis boxplot pada indeks vegetasi TCI dengan hasil prediksi ann.TCI memiliki tinggi box yang sedikit berbeda. Terlihat bahwa nilai data pada TCI yang menyebar memiliki rentang yang lebih besar dibandingkan dengan nilai data ann.TCI.
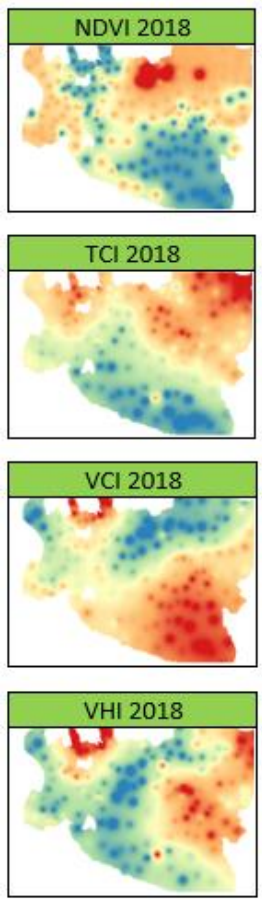
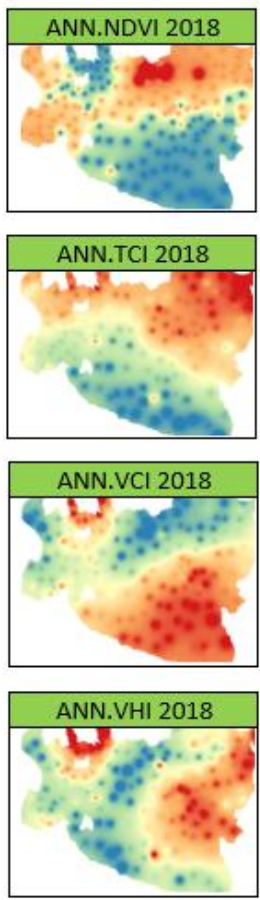
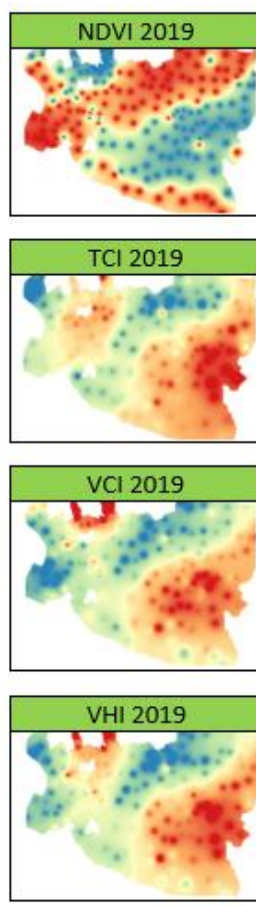
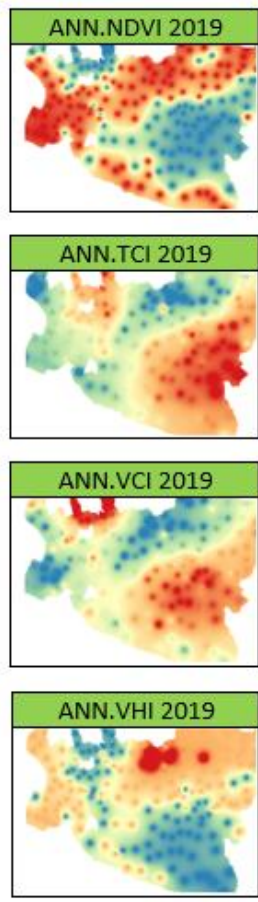

Gambar 6. Gambaran persebaran wilayah potensi kekeringan sedang (Middle Risk) dan tinggi (High Risk) antara indeks vegetasi dengan hasil klasifikasi menggunakan ANN

Langkah selanjutnya yaitu melakukan prediksi spasial menggunakan nilai indeks vegetasi dan hasil prediksi menggunakan Inverse Distance Weighted (IDW) to memvisualisasikan pola spasial wilayah potensi kekeringan sedang dan potensi kekeringan tinggi. Hasil yang didapatkan berupa peta risiko kekeringan tingkat desa yang ditunjukkan pada Gambar 5. Pada Gambar 6 menunjukkan terdapat beberapa bagian yang memiliki warna cerah mengelilingi warna yang cenderung lebih gelap, bagian tersebut merupakan centroid yang merupakan hasil tahapan sebelum melakukan interpolasi IDW. Hasil interpolasi indeks vegetasi dan prediksi kemudian dikelompokkan sesuai warna spasial dimana potensi kekeringan sedang (Middle Risk) memiliki gradasi warna biru muda cenderung tua dan potensi kekeringan tinggi (High Risk) warna oren cenderung merah. Juga dilakukan perhitungan Moran's I untuk mendapatkan nilai autokorelasi spasial antar titik pengamatan. Hasil pada Tabel 6 menunjukkan bahwa keseluruhan nilai autokorelasi spasial indeks vegetasi maupun hasil prediksi menunjukkan positive autocorrelation.

Tabel 6. Analisis Moran's I pada indeks vegetasi dan hasil klasifikasi

\begin{tabular}{ccl}
\hline Indeks Vegetasi & Moran's I & Interpretasi \\
\hline NDVI 2018 & 0.543 & Positive Autocorrelation \\
\hline NDVI 2019 & 0.471 & Positive Autocorrelation \\
\hline ann.NDVI 2018 & 0.599 & Positive Autocorrelation \\
\hline ann.NDVI 2019 & 0.498 & Positive Autocorrelation \\
\hline TCI 2018 & 0.723 & Positive Autocorrelation \\
\hline
\end{tabular}

TRANSFORMATIKA Vol. 18, No. 1, July 2020: $13-24$ 


\begin{tabular}{cll}
\hline TCI 2019 & 0.710 & Positive Autocorrelation \\
\hline ann.TCI 2018 & 0.760 & Positive Autocorrelation \\
\hline ann.TCI 2019 & 0.741 & Positive Autocorrelation \\
\hline VCI 2018 & 0.774 & Positive Autocorrelation \\
\hline VCI 2019 & 0.654 & Positive Autocorrelation \\
\hline ann.VCI 2018 & 0.778 & Positive Autocorrelation \\
\hline ann.VCI 2019 & 0.661 & Positive Autocorrelation \\
\hline VHI 2018 & 0.623 & Positive Autocorrelation \\
\hline VHI 2019 & 0.708 & Positive Autocorrelation \\
\hline ann.VHI 2018 & 0.634 & Positive Autocorrelation \\
\hline ann.VHI 2019 & 0.717 & Positive Autocorrelation \\
\hline
\end{tabular}

\section{Kesimpulan}

Berdasarkan hasil yang didapatkan dari penelitian maka dapat disimpulkan bahwa algoritma ANN cukup akurat dengan hasil akurasi sebesar 93.88\% dan nilai Kappa sebesar $87.68 \%$, namun berdasarkan perbandingan akurasi antar metode Random Forest memiliki nilai akurasi dan nilai Kappa yang lebih unggul yaitu sebesar $99.91 \%$ dan $99.81 \%$. Klasifikasi wilayah kekeringan dengan potensi kekeringan tinggi (High Risk) menggunakan metode ANN mendapatkan 9 desa diantaranya Desa Baleharjo, Banguntapan, Jagalan, Logandeng, Ngeposari, Ngestiharjo, Sambirejo dan Tirtonirmolo. Dengan menggunakan prediksi spasial juga dapat menghasilkan peta persebaran wilayah seperti pada Gambar 6 untuk membedakan wilayah yang masuk dalam kategori potensi kekeringan sedang (Middle Risk) dan potensi kekeringan tinggi (High Risk). Hasil analisis Moran's I menunjukkan bahwa semua indeks vegetasi maupun hasil prediksi menggunaka ANN memiliki positive autocorrelation.

\section{Daftar Pustaka}

[1] M. R. Amri, Indeks Risiko Bencana Indonesia. Jakarta: BNPB, 2016.

[2] L. Kurniawan, S. Triutomo, R. Yunus, M. R. Amri, and A. A. Hantyanto, Risiko Bencana Indonesia, 1st ed. Direktorat Pengurangan Risiko Bencana Deputi Bidang Pencegahan dan Kesiapsiagaan, 2014.

[3] P. Togatorop, S. Subiyanto, and A. Wijaya, "Pemetaan Potensi Bencana Aliran Lava Gunung Sinabung Menggunakan Citra Aster Gdem," J. Geod. Undip, Vol. 5, No. 2, Pp. 87-96, 2016.

[4] D. Hastuti, Sarwono, and C. Muryani, "Mitigasi Kesiapsiagaan dan Adaptasi Masyarakat terhadap Bahaya Kekeringan Kabupaten Grobogan," J. GeoEco, Vol. 3, No. 1, Pp. 47-57, 2017.

[5] F. Rahman, A. Sukmono, and B. D. Yuwono, "Analisis Kekeringan Pada Lahan Pertanian Menggunakan Metode NDDI dan Perka BNPB Nomor 02 Tahun 2012 (Studi Kasus: Kabupaten Kendal Tahun 2015)," J. Geod. Undip, Vol. 6, No. 4, Pp. 274-284, 2017.

[6] I. Nuarsa, I. Adnyana, and A. As-syakur, "Pemetaan Daerah Rawan Kekeringan Di BaliNusa Tenggara Dan Hubungannya Dengan Enso 2) Menggunakan Aplikasi Data Penginderaan Jauh,” Bumi Lestari, Vol. 15, No. 1, Pp. 20-30, 2015.

[7] I. Sholikhati, D. Harisuseno, E. Suhartanto, M. Program, M. Teknik, and P. Universitas, "Studi Identifikasi Indeks Kekeringan Hidrologis Pada Daerah Aliran Sungai ( Das ) Berbasis Sistem Informasi Geografis ( Sig )," 2008.

[8] A. A. Ashazy and A. B. Cahyono, "Analisis Indeks Vegetasi Menggunakan Citra Satelit Formosat-2 Di Daerah Perkotaan (Studi Kasus: Surabaya Timur)," Geoid, Vol. 9, No. 1, p. $88,2013$.

[9] S. N. Lufilah, A. D. Makalew, and B. Sulistyantara, "Pemanfaatan Citra Landsat 8 Untuk Istimewa Yogyakarta Menggunakan Citra Landsat 8 Operational Land Imager (OLI) 
Analisis Indeks Vegetasi Di Dki Jakarta,”J. Lanskap Indones., Pp. 73-80, 2017.

[10] E. K. Andana, "Pengembangan Data Citra Satelit Landsat-8 Untuk Pemetaan Area Tanaman Hortikultura Dengan Berbagai Metode Algoritma Indeks Vegetasi (Studi Kasus: Kabupaten Malang Dan Sekitarnya)," Nas. Manaj. Teknol., Vol. 9, No. Sistem Informasi Geografis, Pp. 1-10, 2015.

[11] D. Amliana, Y. Prasetyo, and A. Sukmono, "Analisis Perbandingan Nilai NDVI Landsat 7 Dan Landsat 8 Pada Kelas Tutupan Lahan (Studi Kasus : Kota Semarang, Jawa tengah)," J. Geod. Undip, Vol. 5, No. 1, Pp. 264-274, 2016.

[12] F. S. Wirandha, Marwan, and Nizamuddin, "Klasifikasi Penggunaan Lahan Menggunakan Citra Satelit Spot-6 di Kabupaten Aceh Barat," Semin. Nas. dan Expo Tek. Elektro 2015, 2015.

[13] WMO and GWP, Handbook of Drought Indicators and Indices (M. Svoboda and B.A. Fuchs). Integrated Drought Management Programme (IDMP). Integrated Drought Management Programme (IDMP), Integrated Drought Management Tools and Guidelines Series 2. Geneva., No. 1173. 2016.

[14] S. Yulianto, J. Prasetyo, S. Silvianugroho, K. D. Hartomo, and J. Diponegoro, "Penentuan Wilayah Resiko Bencana Kekeringan di Jawa Tengah Menggunakan Machine Learning dan Indeks Vegetasi pada Citra Landsat 8 OLI," Indones. J. Comput. Model., 2018.

[15] F. N. Kogan, "Global Drought Watch from Space," Bull. Am. Meteorol. Soc., Vol. 78, No. 4, Pp. 621-636, 1997.

[16] A. Setyono and S. Novianto, "Penerapan Interpolasi Linier Untuk Deteksi Garis Lurus Pada Citra," TechNo.com, Vol. 12 No. 3, No. 3, Pp. 143-149, 2013.

[17] Z. Ibrahim, D. Isa, R. Rajkumar, and G. Kendall, "Document zone content classification for technical document images using artificial neural networks and suPport vector machines," 2nd Int. Conf. APpl. Digit. Inf. Web Technol. ICADIWT 2009, Issue. September, Pp. 345-350, 2009.

[18] H. D. Purnomo, K. D. Hartomo, and S. Y. J. Prasetyo, "Artificial Neural Network for Monthly Rainfall Rate Prediction," J. Phys. Conf. Ser., Vol. 755, No. 1, 2016.

[19] S. Yulianto, J. Prasetyo, K. D. Hartomo, and M. C. Paseleng, "Satellite Imagery and Machine Learning of Autocorrelation for Aridity Disaster Risk Classification using Vegetation Indices," Vol. 9, No. 3, Pp. 1-16, 2015.

[20] G. Garnero and D. Godone, "Comparisons between different interpolation techniques," Int. Arch. Photogramm. Remote Sens. Spat. Inf. Sci. - ISPRS Arch., Vol. 40, No. 5W3, Pp. 139-144, 2013.

TRANSFORMATIKA Vol. 18, No. 1, July $2020: 13-24$ 